\title{
Baseline Sensitivity of Monilinia fructicola from China to the DMI Fungicide SYP-Z048 and Analysis of DMI-Resistant Mutants
}

F. P. Chen, J. R. Fan, T. Zhou, and X. L. Liu, College of Agriculture and Biotechnology, China Agricultural University, Beijing 100193; J. L. Liu, Shen Yang Research Institute of Chemical Industry, Shenyang 110021, China; and G. Schnabel, Department of Entomology, Soils and Plant Sciences, Clemson University, Clemson, SC 29634

\begin{abstract}
Chen, F. P., Fan, J. R., Zhou, T., Liu, X. L., Liu, J. L., and Schnabel, G. 2012. Baseline sensitivity of Monilinia fructicola from China to the DMI fungicide SYP-Z048 and analysis of DMI-resistant mutants. Plant Dis. 96:416-422.

Sterol $14 \alpha$-demethylase inhibitors (DMIs) continue to be important in the management of brown rot of Monilinia spp. worldwide. In this study, the sensitivity of 100 Monilinia fructicola isolates from four unsprayed orchards and two packinghouses in Beijing, China, to the new DMI fungicide SYP-Z048 was evaluated and ranged from 0.003 to 0.039 and 0.016 to $0.047 \mu \mathrm{g} / \mathrm{ml}$, respectively. Laboratory mutants resistant to SYP-Z048 were generated using UV irradiation but no mutants occurred spontaneously. Resistance was stable after 10 weekly consecutive transfers on fungicide-free medium. Three parameters, including growth rate, sporulation in vitro, and lesion area, were significantly different when sensitive isolates and resistant mutants were analyzed as groups. Mutants grew more slowly and developed significantly smaller lesions on detached fruit, and their sporulation ability in vitro was reduced. Cross resistance was found between SYP-

Z048 and propiconazole $(\rho=0.82, P<0.0001)$ but not between SYPZ048 and tridemorph, carbendazim, procymidone, azoxystrobin, or pyrimethanil. SYP-Z048 resistance in mutants exhibiting 50\% mycelial growth inhibition values greater than $0.3 \mu \mathrm{g} / \mathrm{ml}$ was correlated with the presence of a mutation in the CYP51 gene that encodes the target protein for DMI fungicides. The mutation caused an amino acid change from tyrosine to phenylalanine at position 136 (Y136F). To our knowledge, this is the first baseline sensitivity of $M$. fructicola collected from China to a DMI fungicide. The inability of $M$. fructicola to generate spontaneous DMI-resistant mutants coupled with reduced fitness of Y136F mutants can explain why this target site mutation has not yet emerged as a DMI fungicide resistance determinant in M. fructicola field populations worldwide.
\end{abstract}

Monilinia fructicola (G. Winter) Honey causes brown rot of stone fruit in many production areas of the world, including Asia, Europe, Africa, North America, Central America, the Caribbean, South America, and Oceania (35). The fungus can cause blossom blight, twig canker, and pre- and postharvest fruit rot $(17,27)$. Many approaches have been studied to control the disease, including cultivar resistance (39), the use of biocontrol agents (20), physical factors (21), and inoculum reduction (12), but most effective are preharvest and postharvest fungicide applications.

Sterol $14 \alpha$-demethylase inhibitors (DMIs) have a major role in chemical control of brown rot in commercial orchards of the United States and Europe since the 1980s. In China, however, many growers are only starting to use DMI fungicides for the production of high-quality fruit. In contrast to other fungicides, such as methyl benzimidazole carbamates (29-31), resistance to DMIs has just started to emerge $(26,32,43)$ and does not yet play a significant role globally. Even in production areas with documented DMI fungicide resistance, members of the same chemical class may still be used effectively if the intrinsic activity (the relative ability of a drug-receptor complex to produce a maximum functional response) of the active ingredient from a new product is greater than that of the industry standard or if the recommended application rate of the industry standard or any other registered DMI is increased $(15,16)$.

Pathogen populations are capable of adjusting in response to the selection pressure of changing environments. DMI fungicides applied for disease control in modern agriculture impose immense selection pressure on many plant-pathogenic fungi by inhibiting the sterol $14 \alpha$-demethylase, a critical enzyme in the sterol bio-

Corresponding authors: X. L. Liu, E-mail: seedling@ cau.edu.cn and G. Schnabel, E-mail: schnabe@ @lemson.edu

http://dx.doi.org/10.1094/PDIS-06-11-0495

(C) 2012 The American Phytopathological Society synthesis pathway. Pathogens can adjust to such pressure qualitatively or quantitatively, depending on the underlying resistance mechanism. Either way, the shift in sensitivity is a significant event with practical implications and has to be monitored to sustain disease management. The determination of baseline sensitivities in a pathogen population is a critical step in this process. In China, a baseline sensitivity to DMI fungicides has not been generated for M. fructicola.

Considering that DMI fungicides have been used in the United States and Europe to control brown rot of stone fruit for more than 25 years, it is surprising that control failure due to resistance has only been described in the southeastern United States (i.e., Georgia; 32). Resistant isolates have also been found in South Carolina, New York, Ohio (25), and, more recently, New Jersey (6); however, the disease still can be controlled effectively by increasing the application rate of DMIs. In all cases, resistance was associated with the presence of the genetic element Mona located just upstream of MfCYP51 which, in turn, correlated with MfCYP51 overexpression. Although point mutations in the CYP51 gene, leading to reduced affinity of DMI fungicides to the $14 \alpha$-demethylase, are common DMI fungicide resistance mechanisms in some obligate biotrophic fungi and other ascomycete fungi (7-9,24), such resistance mechanisms have not been observed in Monilinia spp.

The continued and successful use of DMI fungicides even with the emergence of resistance (32) justifies the development of new fungicides in this class. SYP-Z048 (5-(4-chlorophenyl)-2,3-dimethyl-3-(pyridine-3)-oxazoline) is a novel oxazole derivative fungicide inhibiting ergosterol biosynthesis in fungi (13). SYPZ048 (Junsiqi, 25\% EC; Shenyang Research Institute of Chemical Industry, Shenyang, China) is registered for controlling gray mold of tomato caused by Botrytis cinerea in China (34) and is currently being developed for other applications, including the management of brown rot of stone fruit.

The objectives of this study were to (i) establish a baseline sensitivity of M. fructicola isolates from China to the DMI fungicide 
SYP-Z048, (ii ) determine cross resistance patterns to other DMIs and other chemical classes of fungicides, and (iii) generate and characterize SYP-Z048-resistant mutants to improve our understanding of resistance development in $M$. fructicola.

\section{Materials and Methods}

Origin, collection, and species identification of single-spore isolates. During summer 2007, 100 peach fruit with symptomatic brown rot lesions were collected from several commercial orchards of Pinggu, Shunyi, and Tongzhou and packinghouses in Haidian and Pinggu districts in Beijing, China (Table 1). According to the producers, DMI fungicides had never been used in any of the commercial orchards prior to sample collection. The origin and spray history of the fruit from the packinghouses was unknown. Some growers stated the occasional use of carbendazim and thiophanatemethyl during preharvest brown rot season.

Conidia were collected from each fruit with a sterile cotton swab, which was then placed into a plastic bag for transport to the laboratory. Conidia were washed off the cotton swab tips using sterile water and the suspension was adjusted to $10^{5}$ conidia $/ \mathrm{ml}$ with a hemacytometer. The suspension $(60 \mu \mathrm{l})$ was evenly distributed onto $1.2 \%$ water agar in petri dishes $(90 \mathrm{~mm}$ in diameter). Dishes were incubated at $22^{\circ} \mathrm{C}$ for $12 \mathrm{~h}$ in darkness. A hyphal tip from a germinating conidium was transferred aseptically to yeastglucose-agar (YGA) medium $(0.5 \%$ yeast extract, $1.8 \%$ glucose, and $1.2 \%$ agar). Although symptoms on fruit and phenotypic appearance of single-spore cultures were indicative for $M$. fructicola, the species was also identified on a molecular level as described previously by Ioos (18). Briefly, the ribosomal internal transcribed spacer (ITS) region ITS1-5.8S-ITS2 was amplified from a subset of isolates covering all locations using $M$. fructicolaspecific primers ITS1Mfcl and ITS4Mfcl. The sequences of four representative isolates were submitted to GenBank (accession numbers GQ979713 to GQ979716). Stock cultures of each isolate were maintained on YGA slants and stored at room temperature $\left(23 \pm 1^{\circ} \mathrm{C}\right)$.

Sensitivity of $M$. fructicola isolates to SYP-Z048. Sensitivity of M. fructicola isolates to SYP-Z048 (Fig. 1) was determined by calculating the $50 \%$ inhibitory dose $\left(\mathrm{EC}_{50}\right.$ value) on fungicideamended medium as described previously (42). Technical-grade SYP-Z048 was dissolved in methanol and added to YGA medium at final concentrations of $0,0.005,0.008,0.01,0.02,0.04$, and 0.08 $\mu \mathrm{g} / \mathrm{ml}$. The final concentration of methanol was $0.1 \%$ in the medium. Dishes were incubated at $22^{\circ} \mathrm{C}$ for 4 days in darkness.

Generation of SYP-Z048-resistant mutants. Ultraviolet (UV) irradiation and spontaneous selection of resistant mycelium and conidia on SYP-Z048-amended media were used in attempts to generate mutants. For the generation of UV irradiation mutants, petri dishes containing 5-day-old actively growing colonies of DMI-sensitive isolates were exposed for 2 min to a 254-nm UV light source placed $12 \mathrm{~cm}$ above the cultures. The exposed colonies were incubated in darkness for $1 \mathrm{~h}$, after which 200 mycelial plugs ( $5 \mathrm{~mm}$ in diameter) were excised from the dishes and transferred to YGA plates amended with SYP-Z048 at $0.2 \mu \mathrm{g} / \mathrm{ml}$. For the generation of spontaneous mutants the same procedure was used but without UV irradiation. After incubation at $22^{\circ} \mathrm{C}$ for 5 to 10 days in darkness, actively growing colonies were transferred to fresh fungicide-free YGA. Five days later, mycelial plugs from the colony periphery were transferred to YGA medium amended with SYP-Z048 at $0.2 \mu \mathrm{g} / \mathrm{ml}$ to confirm resistance.

Conidia from three to five heavily sporulating, field-infected peach fruit were mixed and suspended in $1 \mathrm{ml}$ of sterile water, and $100 \mu \mathrm{l}$ was evenly distributed on YGA medium. Petri plates were exposed to UV light as described above. After 5 days of incubation, developing conidia were harvested using $5 \mathrm{ml}$ of sterile water, and $70 \mu \mathrm{l}$ of $1 \times 10^{7}$ conidia/ml were distributed evenly onto YGA medium amended with SYP-Z048 at $0.2 \mu \mathrm{g} / \mathrm{ml}$ prior to UV irradiation. For the generation of spontaneous mutants, no UV irradiation was applied. Resistance of mutants was verified as described above.

Determination of $\mathrm{EC}_{50}$ values for putative mutants was conducted as described previously, except that SYP-Z048 was used at $0.025,0.05,0.1,0.2,0.5,1.0,1.5$, and $2.0 \mu \mathrm{g} / \mathrm{ml}$. Each isolate was tested in triplicate and the experiment was repeated once. The mutation frequency in percent was calculated as the number of mutants/total number of treated conidia or mycelial plugs $\times 100$; the resistance factor was calculated according to the formula $\mathrm{EC}_{50}$ value of the mutant/mean $\mathrm{EC}_{50}$ value of all baseline isolates included in this study. The generation of mutants and determination of $\mathrm{EC}_{50}$ values were repeated once.

Stability of SYP-Z048 resistance in mutants. Mycelial plugs taken from the periphery of actively growing colonies were transferred weekly for a total of 10 weeks to fresh, fungicide-free YGA medium. Mutants were incubated at $22^{\circ} \mathrm{C}$ in darkness. $\mathrm{EC}_{50}$ values for SYP-Z048 were determined before the transfer and after the 10th transfer. Each mutant was evaluated in triplicate and the entire experiment was repeated once.

Sensitivity of mutants to temperature. Mycelial plugs $(5 \mathrm{~mm}$ in diameter) of each isolate were transferred from the leading edge of an actively growing colony to YGA dishes and incubated in darkness at $4,10,18,22,25,27,30$, or $37^{\circ} \mathrm{C}$. Each isolate was tested in triplicate and average colony diameters were calculated after 5 days of incubation. The growth rate of isolates was calculated at the isolate-specific optimum temperature (i.e., $30^{\circ} \mathrm{C}$ for

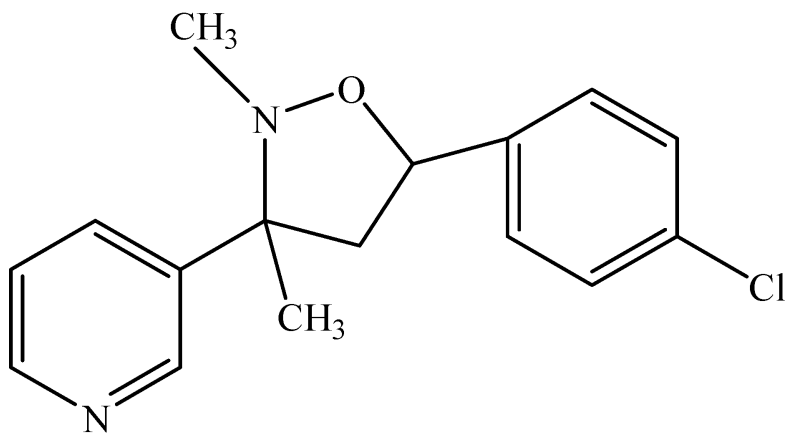

Fig. 1. Chemical structure of SYP-Z048.

Table 1. Origin and sensitivity to SYP-Z048 of Monilinia fructicola field isolates from China

\begin{tabular}{llcccc}
\hline & & & & \multicolumn{2}{c}{ EC $_{\mathbf{5 0}} \mathbf{v a l u e s}(\boldsymbol{\mu g} / \mathbf{m l})^{\mathbf{y}}$} \\
\cline { 3 - 6 } Origin of isolates $^{\mathbf{z}}$ & Source & Year of isolation & Number of isolates & Range & Median \\
\hline ShunyiA & Orchard & 2007 & 8 & $0.005-0.013$ & $0.008 \mathrm{~b}$ \\
ShunyiB & Orchard & 2007 & 12 & $0.006-0.012$ & $0.010 \mathrm{~b}$ \\
PingguA & Orchard & 2007 & 39 & $0.003-0.039$ & $0.019 \mathrm{a}$ \\
Tongzhou & Orchard & 2007 & 23 & $0.016-0.036$ & $0.021 \mathrm{a}$ \\
Haidian & Packinghouse & 2007 & 9 & $0.016-0.031$ & $0.025 \mathrm{a}$ \\
PingguB & Packinghouse & 2007 & 9 & $0.021-0.047$ & $0.023 \mathrm{a}$ \\
\hline
\end{tabular}

${ }^{\mathrm{y}} \mathrm{EC}_{50}=50 \%$ inhibitory dose. Values followed by the same letter within a column are not significantly different according to Kruskal-Wallis one-way analysis of variance on ranks. Mean separation by all pairwise multiple comparison procedures (Dunn's Method; $P \leq 0.05$ ).

${ }^{\mathrm{z}}$ ShunyiA = Dasungezhuang in Shunyi district; ShunyiB = Beixiaoying in Shunyi district; PingguA = Dahuashan in Pinggu district; PingguB =Henanzhai in Pinggu district. 
isolate $\mathrm{B} 511$ and $22^{\circ} \mathrm{C}$ for all other isolates). The experiment was repeated once.

Conidia production and germination rates of mutants in vitro. The number of conidia produced by sensitive isolates and mutants on YGA medium was determined as follows. Mycelial plugs ( $5 \mathrm{~mm}$ in diameter) were harvested in a single straight line from the center to the margin of 1-week-old cultures. The plugs were placed in $15-\mathrm{ml}$ tubes with $10 \mathrm{ml}$ of a $0.1 \%$ aqueous glucose solution, and the suspension was vortexed for $1 \mathrm{~min}$. To determine the rate of germination, the conidial suspension was adjusted to $10^{5}$ to $10^{6}$ conidia/ml and $40 \mu \mathrm{l}$ was spread onto depression slides placed on top of wet filter paper in a petri dish. The depression slides were incubated at $22^{\circ} \mathrm{C}$ for $8 \mathrm{~h}$ in darkness. In total, 200 conidia were assessed per isolate for germination ability under a microscope. Each isolate was tested in triplicate and the entire experiment was repeated once.

Pathogenicity, conidial production, and germination rates of mutants in vivo. Pathogenicity of $M$. fructicola on fresh peach fruit was conducted as described previously (14), with slight modifications. Mature but firm 'Jiubao' peach fruit were purchased from a local supermarket, washed twice with sterile water, and wounded at three equidistant locations $(2 \mathrm{~cm}$ apart) by inserting a cork borer (5 $\mathrm{mm}$ in diameter) about $2 \mathrm{~mm}$ deep. Inoculation was conducted as described previously (14) and the inoculation site was covered with wet cotton for $24 \mathrm{~h}$. Average lesion diameters were recorded after fruit were kept for $48 \mathrm{~h}$ at $22^{\circ} \mathrm{C}, 80 \%$ relative humidity, and a 12-h photoperiod. The experiment was conducted three times with three replicates per experiment. Emerging conidia were scraped off and suspended in 50-ml tubes filled with $10 \mathrm{ml}$ of sterile water. The suspension was vortexed for $3 \mathrm{~min}$ before conidia were quantified with a hemocytometer. Determination of conidial germination was as described above.

Cross-resistance between SYP-Z048 and six fungicides from different chemical classes. In all, 6 DMI-sensitive isolates and 17 mutants with medium to high $\mathrm{EC}_{50}$ values for SYP-Z048 were used to determine cross-resistance between SYP-Z048 and one additional DMI (propiconazole, 95\%; Zhejiang Heben Pesticide \& Chemicals Co., Ltd., China) and five other fungicides of different modes of action, including tridemorph (98.3\%; Zhejiang Shijia Technology Co., Ltd., China), procymidone (98.1\%; Shaanxi Sunger Road Bio-Science Co., Ltd., China), azoxystrobin (analytical standard, Sigma-Aldrich, St. Louis), pyrimethanil (93\%; Jiangsu Limin Chemical Industrial Co., Ltd., China), and carbendazim (98\%; Beihai Hepu Pesticide Co., Ltd., China). The sensitivity assay was conducted as described above, except that glucose-gelatin-agar medium $(0.4 \%$ glucose, $0.4 \%$ gelatin, $0.177 \%$ $\mathrm{K}_{2} \mathrm{HPO}_{4}, 0.036 \% \mathrm{MgSO}_{4} \cdot 7 \mathrm{H}_{2} \mathrm{O}$, and $1.2 \%$ agar) was used for pyrimethanil (4) and salicylhydroxamic acid was added to azoxystrobin-amended medium at $100 \mu \mathrm{g} / \mathrm{ml}$. SYP-Z048, tridemorph, and propiconazole were dissolved in methanol; procymidone, azoxystrobin, and pyrimethanil were dissolved in acetone; and carbendazim was dissolved in $\mathrm{HCl}$ at $0.2 \mathrm{~mol} /$ liter. All fungicides were prepared as $10,000 \mu \mathrm{g} / \mathrm{ml}$ stock solutions and stored at $4{ }^{\circ} \mathrm{C}$ in darkness to maintain and preserve fungicide activity. For each assay, the stocks were diluted to the desired concentrations. The maximum concentration of each solvent in diluted solutions was $0.1 \%$. Colony diameters were measured after 4 days of incubation at $22^{\circ} \mathrm{C}$ and $\mathrm{EC}_{50}$ values were calculated as described above.

Sequencing the MfCYP51 gene from field isolates and SYPZ048-resistant mutants. Genomic DNA of $M$. fructicola was extracted from mycelium using a modified cetyltrimethylammonium bromide (CTAB) method. Mycelium was scraped off the surface of a 5-day-old culture grown on YGA and ground with mortar and pestle in liquid nitrogen. The powder was added to extraction buffer (2\% CTAB, $100 \mathrm{mM}$ Tris-HCl [pH 8.0], $20 \mathrm{mM}$ EDTA [pH $8.0]$, and $1.4 \mathrm{M} \mathrm{NaCl}$ ) and incubated for $30 \mathrm{~min}$ at $65^{\circ} \mathrm{C}$. After extraction with one volume of phenol/chloroform/isoamyl alcohol (25:24:1), DNA was precipitated with one volume of isopropyl alcohol for $10 \mathrm{~min}$ at room temperature $\left(23 \pm 1^{\circ} \mathrm{C}\right)$. The suspension was centrifuged at $12,000 \times g$ for $10 \mathrm{~min}$ and the pellet was washed with $75 \%$ alcohol. DNA was dried in a laminar flow hood and suspended in Tris-EDTA buffer $(10 \mathrm{mM}$ Tris- $\mathrm{HCl}$ and $1 \mathrm{mM}$ EDTA, $\mathrm{pH}$ 8.0). The complete MfCYP51 gene was amplified with primer pair MfCYP51-F and MfCYP51-R as described previously (33). Polymerase chain reaction (PCR) volumes were $50 \mu \mathrm{l}$ containing $1 \times$ PCR buffer, 50 ng of DNA, $0.4 \mu \mathrm{M}$ each primer, 100 $\mu \mathrm{M}$ each dNTP, and $1 \mathrm{U}$ of Taq DNA polymerase (TransGen Biotech Co., Beijing). Amplifications were performed in an MyCycler thermal cycler (Bio-Rad Laboratories, Hercules, CA) programmed for $4 \mathrm{~min}$ at $95^{\circ} \mathrm{C} ; 32$ cycles of $30 \mathrm{~s}$ at $95^{\circ} \mathrm{C}, 30 \mathrm{~s}$ at $58^{\circ} \mathrm{C}$, and 2 min at $72^{\circ} \mathrm{C}$; followed by a final extension step of $10 \mathrm{~min}$ at $72^{\circ} \mathrm{C}$. PCR products were separated in $1.0 \%$ agarose gels in $1 \times$ Tris-acetate-EDTA buffer (40 mM Tris acetate and $1 \mathrm{mM}$ EDTA, pH 8.0), and purified by using a gel extraction kit (TransGen Biotech). The PCR fragment was ligated into vector pEasy T3 (TransGen Biotech) and the vector was inserted into Escherichia coli strain Top 10 (TransGen Biotech) and sequenced at Sunbiotech Co., Beijing. The sequencing primers were vector primers M13F and M13R (forward primer CYPF3, 5'-TACCACGACCTCGACATGGGCTT3'; and reverse primer CYPR5, 5'-GTGTGGAGACGGA GAGTTTC-3') located at positions 783 and 1,243, respectively, of the MfCYP51 start codon. DNA sequences were analyzed with DNAMAN5.2.2.0 (Lynnon BioSoft, Quebec, Canada).

Data analysis. Bartlett's test for homogeneity of variances was performed for repeated experiments. In each study, variances were homogeneous $(P<0.05)$ and, thus, combined data sets were analyzed. The $\mathrm{EC}_{50}$ value for each isolate was calculated by regression analysis using the percentage of growth inhibition against the logarithmic value of fungicide concentration. Significance levels for mean $\mathrm{EC}_{50}$ values were determined due to failure of a normality test $(P=0.048)$ by the Kruskal-Wallis one-way analysis of variance on ranks, and median separation was conducted using all

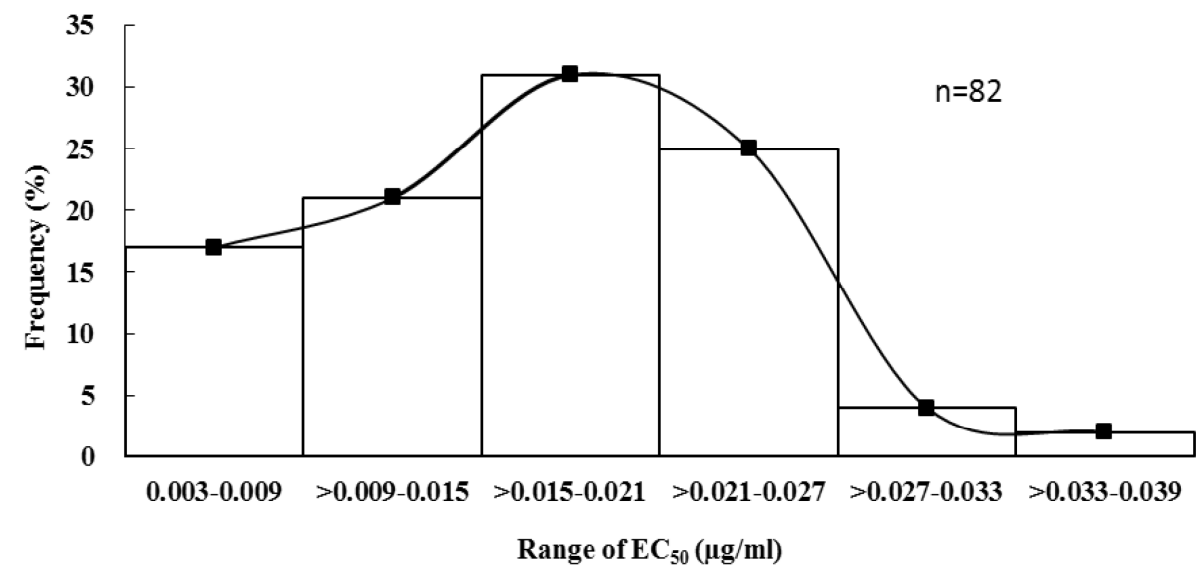

Fig. 2. Sensitivity to SYP-Z048 of 82 baseline isolates of Monilinia fructicola from China. 
pairwise multiple comparison procedures (Dunn's Method). To determine cross-resistance patterns, $\mathrm{EC}_{50}$ values were log transformed prior to Spearman rank correlation analysis. Groups of sensitive and resistant isolates were analyzed in regard to phenotypic characteristic using the $t$ test. Statistical analyses were performed using SigmaStat (version 3.0; SPSS Inc., Chicago).

\section{Results}

Baseline sensitivity of $\boldsymbol{M}$. fructicola to SYP-Z048. $\mathrm{EC}_{50}$ values of isolates from packinghouses and unsprayed orchards ranged from 0.016 to $0.047 \mu \mathrm{g} / \mathrm{ml}$ and 0.003 to $0.039 \mu \mathrm{g} / \mathrm{ml}$ respectively; mean $\mathrm{EC}_{50}$ values were 0.025 and $0.017 \mu \mathrm{g} / \mathrm{ml}$, respectively. $\mathrm{EC}_{50}$

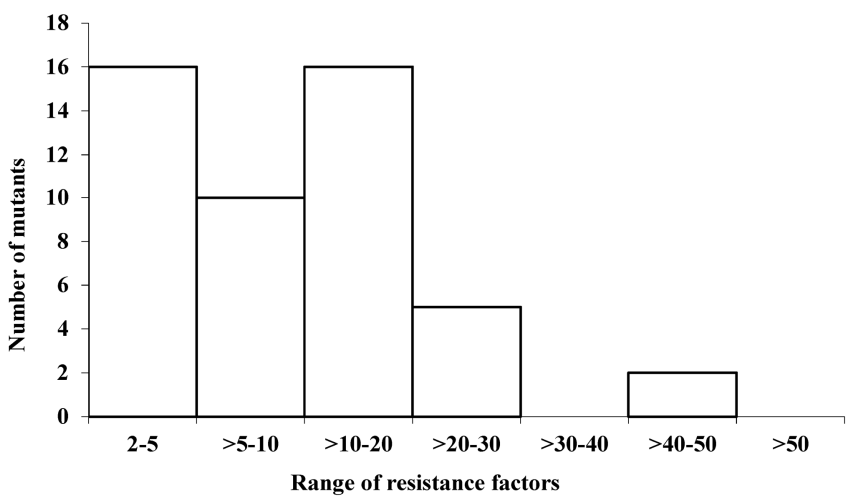

Fig. 3. Frequencies distribution of resistance factors of UV-generated mutants from conidia and mycelium. values for isolates from two of the four unsprayed orchards were significantly lower than those of packinghouse populations (Table 1). Isolates from all orchards taken together formed a unimodel curve (Fig. 2), with no indication of a resistant subpopulation.

Selection of SYP-Z048-resistant mutants. UV irradiation of mycelium or conidia generated a total of 30 and 19 mutants, respectively. No mutants were obtained by spontaneous selection. $\mathrm{EC}_{50}$ values of the mutants from mycelium ranged from 0.045 to $0.529 \mu \mathrm{g} / \mathrm{ml}$, with corresponding resistance factors of 2.6 to 30.4 . The average mutation frequency was $1.8 \times 10^{-2} . \mathrm{EC}_{50}$ values of the mutants from conidia ranged from 0.048 to $0.885 \mu \mathrm{g} / \mathrm{ml}$ with corresponding resistance factors of 2.7 to 50.8. The average mutation frequency from conidia was $8.3 \times 10^{-10}$ (data not shown). Resistance factors of 42 mutants were between 2 and 20; 2 mutants had resistance factors greater than 40 (Fig. 3).

Fitness of SYP-Z048-resistant mutants. After 10 transfers on SYP-Z048-free YGA, the sensitivity to SYP-Z048 of all mutants was stable (data not shown). The temperature-sensitivity studies showed that $22^{\circ} \mathrm{C}$ was most suitable for mycelial growth of sensitive isolates and of all resistant mutants except for one (Table 2).

The average growth rate of all sensitive isolates was $1.2 \mathrm{~cm} /$ day, which was significantly higher $(P=0.032)$ than the average growth rate of resistant mutants (Table 3 ). Mutants were also impaired in respect to in vitro sporulation $\left(33.4 \times 10^{5} \mathrm{conidia} / \mathrm{cm}^{2}\right.$ for the sensitive isolates and $2.3 \times 10^{5}$ conidia $/ \mathrm{cm}^{2}$ for the resistant mutants; $P$ $=0.002)$ and lesion area produced on detached peach fruit $\left(9.6 \mathrm{~cm}^{2}\right.$ for the sensitive isolates and $3.1 \mathrm{~cm}^{2}$ for the resistant mutants, $P=$ 0.004; Table 3).

Cross-resistance between SYP-Z048 and six fungicides of different chemical classes. For 17 SYP-Z048-resistant mutants

Table 2. Temperature sensitivity of field isolates and SYP-Z048-resistant mutants of Monilinia fructicola

\begin{tabular}{|c|c|c|c|c|c|c|c|c|c|c|}
\hline \multirow[b]{2}{*}{$T\left({ }^{\circ} \mathbf{C}\right)^{\mathbf{z}}$} & \multicolumn{10}{|c|}{ Diameter of colony $(\mathrm{cm})^{y}$} \\
\hline & MSB11 $^{\text {S }}$ & MBJA8 $^{S}$ & MPA18 $^{S}$ & $\mathbf{A 3 0 8 1}^{\mathrm{MR}}$ & $\mathrm{B5103}^{\mathrm{R}}$ & $\mathrm{B607}^{\mathrm{R}}$ & B6012 ${ }^{\mathrm{R}}$ & B615 $^{\mathrm{R}}$ & B506 $^{\text {R }}$ & B511 $^{\mathrm{R}}$ \\
\hline 37 & $0 \mathrm{e}$ & $0 \mathrm{f}$ & $0 \mathrm{f}$ & $0 \mathrm{f}$ & $0 \mathrm{f}$ & $0 \mathrm{f}$ & $0 \mathrm{e}$ & $0 \mathrm{c}$ & $0 \mathrm{~d}$ & $0 \mathrm{e}$ \\
\hline 30 & $(5.1 \pm 0.6) b$ & $(5.5 \pm 0.2) \mathrm{b}$ & $(4.3 \pm 0.1) \mathrm{d}$ & $(3.9 \pm 0.0) \mathrm{d}$ & $(3.7 \pm 0.1) \mathrm{d}$ & $(3.7 \pm 0.1) \mathrm{d}$ & $(4.5 \pm 0.0) b c$ & $(3.6 \pm 0.2) b$ & $(3.1 \pm 0.1) \mathrm{ab}$ & $(2.7 \pm 0.2) \mathrm{a}$ \\
\hline 27 & $(6.3 \pm 0.2) \mathrm{a}$ & $(5.4 \pm 0.1) b c$ & $(5.5 \pm 0.1) b$ & $(4.3 \pm 0.3) \mathrm{c}$ & $(4.5 \pm 0.1) \mathrm{b}$ & $(4.3 \pm 0.1) \mathrm{c}$ & $(4.4 \pm 0.1) \mathrm{c}$ & $(4.5 \pm 0.1) \mathrm{a}$ & $(3.0 \pm 0.0) b$ & $(2.3 \pm 0.3) \mathrm{ab}$ \\
\hline 25 & $(6.3 \pm 0.2) \mathrm{a}$ & $(5.3 \pm 0.1) \mathrm{c}$ & $(5.4 \pm 0.1) b$ & $(4.8 \pm 0.3) b$ & $(4.2 \pm 0.1) \mathrm{c}$ & $(4.5 \pm 0.1) \mathrm{b}$ & $(4.6 \pm 0.1) \mathrm{b}$ & $(4.2 \pm 0.4) \mathrm{a}$ & $(2.7 \pm 0.1) b$ & $(1.8 \pm 0.3) \mathrm{c}$ \\
\hline 22 & $(6.4 \pm 0.1) \mathrm{a}$ & $(5.9 \pm 0.1) \mathrm{a}$ & $(5.8 \pm 0.1) \mathrm{a}$ & $(5.6 \pm 0.1) \mathrm{a}$ & $(4.9 \pm 0.2) \mathrm{a}$ & $(5.0 \pm 0.1) \mathrm{a}$ & $(5.3 \pm 0.1) \mathrm{a}$ & $(4.5 \pm 0.0) \mathrm{a}$ & $(3.4 \pm 0.1) \mathrm{a}$ & $(2.2 \pm 0.3) \mathrm{b}$ \\
\hline 18 & $(4.6 \pm 0.2) \mathrm{c}$ & $(5.0 \pm 0.0) \mathrm{d}$ & $(4.6 \pm 0.1) \mathrm{c}$ & $(4.9 \pm 0.1) b$ & $(4.8 \pm 0.1) \mathrm{a}$ & $(4.5 \pm 0.1) b$ & $(4.4 \pm 0.1) b c$ & $(4.2 \pm 0.2) \mathrm{a}$ & $(2.8 \pm 0.3) b$ & $(2.0 \pm 0.1) b c$ \\
\hline 10 & $(2.2 \pm 0.1) \mathrm{d}$ & $(2.4 \pm 0.2) \mathrm{e}$ & $(1.5 \pm 0.1) \mathrm{e}$ & $(1.1 \pm 0.1) \mathrm{e}$ & $(1.1 \pm 0.1) \mathrm{e}$ & $(1.4 \pm 0.1) \mathrm{e}$ & $(2.1 \pm 0.1) \mathrm{d}$ & $(0.5 \pm 0.2) b$ & $(1.0 \pm 0.3) \mathrm{c}$ & $(0.2 \pm 0.2) \mathrm{d}$ \\
\hline 4 & $0 \mathrm{e}$ & $0 \mathrm{f}$ & $0 \mathrm{f}$ & $0 \mathrm{f}$ & $0 \mathrm{f}$ & $0 \mathrm{f}$ & $0 \mathrm{e}$ & $0 \mathrm{c}$ & $0 \mathrm{~d}$ & $0 \mathrm{e}$ \\
\hline
\end{tabular}

y Superscript S, MR, and R represent sensitive, moderately resistant, and resistant isolates, respectively. Isolate A3081 did not carry a mutation at the Y136F position. Values followed by the same letter within a column are not significantly different according to Fisher's least significant difference test $(P<0.05)$.

z Temperature.

Table 3. Phenotypic characteristics of field isolates and SYP-Z048-resistant mutants of Monilinia fructicola

\begin{tabular}{|c|c|c|c|c|c|c|}
\hline \multirow[b]{2}{*}{ Isolate, mutant $\mathbf{t}^{\mathrm{y}}$} & \multirow[b]{2}{*}{$\begin{array}{c}\text { Growth } \\
(\mathrm{cm} / \text { day })^{z}\end{array}$} & \multicolumn{2}{|c|}{ On yeast-glucose-agar medium } & \multicolumn{3}{|c|}{ On peach fruit } \\
\hline & & $\begin{array}{c}\text { Sporulation } \\
\left(\times 10^{5} / \mathrm{cm}^{2}\right)\end{array}$ & $\begin{array}{c}\text { Germination rate } \\
\qquad(\%)\end{array}$ & $\begin{array}{l}\text { Sporulation } \\
\left(\times 10^{5} / \text { lesion }\right)\end{array}$ & $\begin{array}{c}\text { Germination rate } \\
(\%)\end{array}$ & $\begin{array}{l}\text { Lesion area } \\
\qquad\left(\mathrm{cm}^{2}\right)\end{array}$ \\
\hline MBJA8 ${ }^{\mathrm{S}}$ & $1.17 \mathrm{~b}$ & $48.5 \mathrm{a}$ & $92.3 \mathrm{a}$ & $29.0 \mathrm{a}$ & $89.7 \mathrm{ab}$ & $10.59 \mathrm{a}$ \\
\hline $\operatorname{MSB} 11^{\mathrm{S}}$ & $1.28 \mathrm{a}$ & $35.4 \mathrm{~b}$ & $95.5 \mathrm{a}$ & $19.3 \mathrm{ab}$ & $84.5 \mathrm{bc}$ & $8.90 \mathrm{~b}$ \\
\hline MPA18 & $1.09 \mathrm{~cd}$ & $16.3 \mathrm{c}$ & $70.7 \mathrm{c}$ & $4.3 \mathrm{c}$ & $81.7 \mathrm{~cd}$ & $9.40 \mathrm{~b}$ \\
\hline A3081 ${ }^{\mathrm{MR}}$ & $1.11 \mathrm{c}$ & $4.2 \mathrm{~d}$ & $83.2 \mathrm{~b}$ & $29.0 \mathrm{a}$ & $90.1 \mathrm{ab}$ & $8.01 \mathrm{c}$ \\
\hline $\mathrm{B} 607^{\mathrm{R}}$ & $0.99 \mathrm{e}$ & $6.4 \mathrm{~cd}$ & $74.2 \mathrm{c}$ & $7.0 \mathrm{bc}$ & $76.7 \mathrm{~d}$ & $5.42 \mathrm{~d}$ \\
\hline $\mathrm{B} 6012^{\mathrm{R}}$ & $1.05 \mathrm{~d}$ & $3.6 \mathrm{~d}$ & $88.2 \mathrm{ab}$ & $11.3 \mathrm{bc}$ & $93.0 \mathrm{a}$ & $4.89 \mathrm{~d}$ \\
\hline B5103 ${ }^{\mathrm{R}}$ & $0.97 \mathrm{e}$ & $2.6 \mathrm{~d}$ & $83.0 \mathrm{~b}$ & $25.3 \mathrm{a}$ & $94.0 \mathrm{a}$ & $5.13 \mathrm{~d}$ \\
\hline $\mathrm{B} 615^{\mathrm{R}}$ & $0.90 \mathrm{f}$ & $1.0 \mathrm{~d}$ & $60.7 \mathrm{~d}$ & $9.3 \mathrm{bc}$ & $54.7 \mathrm{e}$ & $3.04 \mathrm{e}$ \\
\hline $\mathrm{B} 506^{\mathrm{R}}$ & $0.67 \mathrm{~g}$ & $0 \mathrm{e}$ & $0 \mathrm{e}$ & $0 \mathrm{~d}$ & $0 \mathrm{f}$ & $0 \mathrm{f}$ \\
\hline $\mathrm{B} 511^{\mathrm{R}}$ & $0.44 \mathrm{~h}$ & $0 \mathrm{e}$ & $0 \mathrm{e}$ & $0 \mathrm{~d}$ & $0 \mathrm{f}$ & $0 \mathrm{f}$ \\
\hline All sensitive & $1.2 \mathrm{a}$ & $33.4 \mathrm{a}$ & $86.2 \mathrm{a}$ & $17.5 \mathrm{a}$ & $85.3 \mathrm{a}$ & $9.6 \mathrm{a}$ \\
\hline All resistant & $0.8 \mathrm{~b}$ & $2.3 \mathrm{~b}$ & $51.0 \mathrm{a}$ & $8.8 \mathrm{a}$ & $53.1 \mathrm{a}$ & $3.1 \mathrm{~b}$ \\
\hline$P$ & 0.032 & 0.002 & ns & ns & ns & 0.004 \\
\hline
\end{tabular}

x Values of individual isolates followed by the same letter within a column are not significantly different according to Fisher's least significant difference test $(P \leq 0.05)$; ns = not significant. SYP-Z048-sensitive isolates (MBJA8, MSB11, and MPA18) and resistant mutants containing the Y136F mutation (B607, B6012, B5103, B615, B506, and B511) were analyzed separately in groups using the $t$ test.

y Superscript S, MR, and R represent sensitive, moderately resistant, and resistant isolates, respectively. Isolate A3081 does not carry a mutation at the Y136F position.

${ }^{\mathrm{z}}$ Growth rate was tested at the growth optimum temperature: $28^{\circ} \mathrm{C}$ for isolate $\mathrm{B} 511$ and $22^{\circ} \mathrm{C}$ for all others. 
and 6 sensitive field isolates, there was no correlation between sensitivity to SYP-Z048 and that to tridemorph, procymidone, azoxystrobin, carbendazim, or pyrimethanil. A positive correlation was observed between sensitivity to SYP-Z048 and that to propiconazole $(\rho=0.82, P<0.0001$; Fig. 4$)$.

Sequencing of MfCYP51 from field isolates and SYP-Z048resistant mutants. Amplification of the wild-type isolate and mutant DNA with primers MfCYP51-F and MfCYP51-R yielded a single band of the expected size $(1,685 \mathrm{bp})$. The putative amino acid sequences of sensitive field isolates $\left(\mathrm{EC}_{50}<0.033 \mu \mathrm{g} / \mathrm{ml}\right)$ and resistant mutants $\left(\mathrm{EC}_{50}>0.342 \mu \mathrm{g} / \mathrm{ml}\right)$ differed at position 136 , where tyrosine was replaced by phenylalanine. Mutant A3081, which exhibited moderate resistance to SYP-Z048 $\left(\mathrm{EC}_{50}=0.097\right.$ $\mu \mathrm{g} / \mathrm{ml}$ ) was the only mutant without the Y136F mutation (Table 3). Mutant B6012 and field isolate MSB11 had serine at position 161 and position 490, respectively (Table 4).

\section{Discussion}

In this study, we established the baseline sensitivity of $M$. fructicola isolates from three districts of Beijing, China, to the DMI fungicide SYP-Z048 and investigated laboratory mutants exhibiting the Y136F mutation in the MfCYP51. The point mutation conferred resistance to another DMI fungicide (propiconazole) but not to chemicals of the five other classes. Mutants also exhibited impaired fitness for some parameters evaluated, which may be a reason why this mutation has not yet been discovered in commercial orchards worldwide.

Mutants of M. fructicola were not selected spontaneously in the laboratory on YGA medium amended with SYP-Z048 in this study. The fungus had to be exposed to UV irradiation in order to generate SYP-Z048-resistant mutants. This is in contrast to a previous study reporting frequent development of Mycosphaerella graminicola mutants resistant to azole fungicides via spontaneous selection at a relatively high rate of about $10^{-4}(44)$. Similar frequencies were reported for other filamentous fungi, including Aspergillus nidulans to imazalil (38) and Nectria haematococca to fenarimol (19). The inability of Monilinia fructicola to generate SYP-Z048-resistant spontaneous mutants is mirrored by the fact that mutants with target site mutations revealing $\mathrm{EC}_{50}$ values as high as observed in this study have not been observed in commercial orchards sprayed
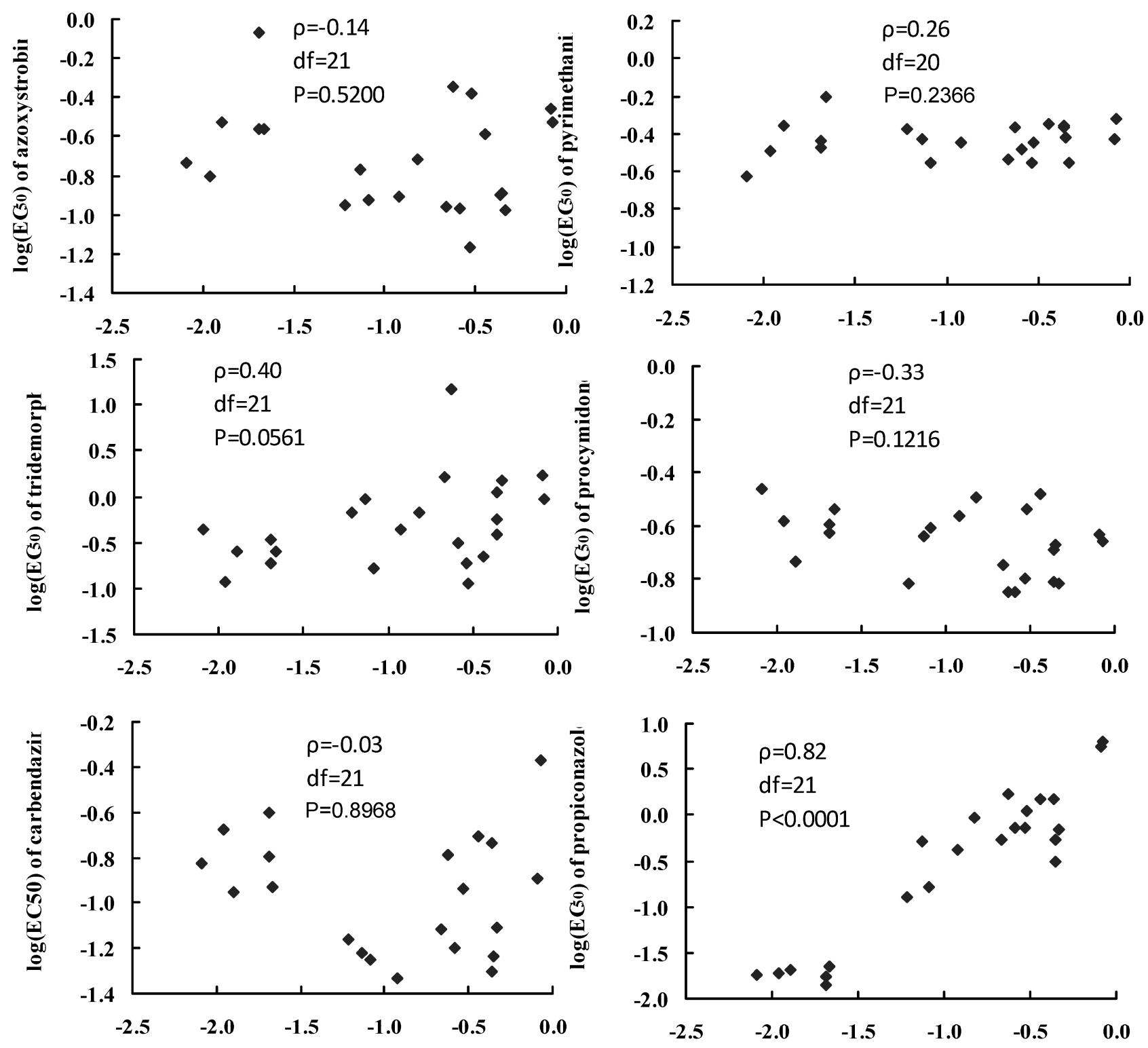

$\log \left(\mathrm{EC}_{50}\right)$ of S YP-Z048

$\log \left(\mathrm{EC}_{50}\right)$ of S YP-Z048

Fig. 4. Cross-resistance between SYP-ZO48 and azoxystrobin, pyrimethanil, tridemorph, procymidone, carbendazim, or propiconazole by rank correlation analysis. Data shown in logarithmic values of effective concentrations for $50 \%$ mycelial growth inhibition (log $\mathrm{EC}_{50}$ ) among Monilinia fructicola for fungicide combinations. 
with DMI fungicides multiple times per year for more than three decades. Currently, existing DMI resistance in M. fructicola field isolates is based on overexpression of the target enzyme $(25,26)$ conferring resistance levels lower than observed in most of our mutants.

$\mathrm{EC}_{50}$ values for SYP-Z048 of isolates from packinghouses and unsprayed orchards were low but median values of two out of four unsprayed orchards were significantly lower than packinghouse isolates. This difference could be attributed to the comparably low sample size of the packinghouse populations or it could, indeed, indicate a slight but significant shift toward reduced sensitivity. Whether packinghouse isolates were exposed to DMI fungicides and, thus, subjected to selection pressure is unknown. The mean $\mathrm{EC}_{50}$ value for SYP-Z048 in baseline orchard populations from China was $0.017 \mu \mathrm{g} / \mathrm{ml}$, which is similar to values reported for propiconazole in M. fructicola baseline populations from Seneca, SC $(0.03 \mu \mathrm{g} / \mathrm{ml} ; 43)$, Anderson, SC $(0.025 \mu \mathrm{g} / \mathrm{ml} ; 32)$, and values reported for tebuconazole in California $(0.016 \mu \mathrm{g} / \mathrm{ml}$; 41$)$. All isolates combined revealed no resistant subpopulation; thus, the sensitivity range can be considered a baseline sensitivity of $M$. fructicola to the DMI fungicide SYP-Z048. The baseline sensitivity to SYP-Z048 reported in this study will be useful in detecting future potential shifts in DMI fungicide sensitivity in general and for SYP-Z048 specifically in China.

We found strong positive cross-resistance between SYP-Z048 and propiconazole in our mutants, indicating that the resistance mechanism found in the mutants confers resistance to DMI fungicides of different chemistries. Additional studies with field isolates from the southeastern United States sensitive and resistant to the DMI fungicide propiconazole also revealed strong cross resistance to SYP-Z048 (data not shown). The results confirm that SYP-Z048 is a typical DMI fungicide.

Plant pathogen resistance to DMI fungicides is most commonly conferred by (i) mutations in the CYP51 gene encoding the target enzyme sterol $14 \alpha$-demethylase, (ii) increased expression of the CYP51 gene, or (iii) increased expression of ATP-binding cassette transporters which result in multidrug resistance (28). Although ABC transporter activity has largely conferred low resistance levels, point mutations in and overexpression of the CYP51 gene are mechanisms of great economic importance. Arguably, the most powerful mechanism is the alteration of the target site due to point mutations $(7,9,11,24,36,40)$, because an increase in field rates would not substantially improve DMI fungicide efficacy due to the inability of the fungicide to bind to the target protein.

Despite the three-decade-long, regular application of DMI fungicides in commercial stone fruit orchards in the United States and Europe, field resistance of Monilinia spp. to DMIs has only been documented for M. fructicola from peach in Georgia and South Carolina (32,43). The resistance is based on MfCYP51 overexpression associated with the genetic element Mona located 117 bp upstream of MfCYP51 (26). This mechanism of resistance provides protection from DMIs with comparably weak intrinsic activity and can be overcome by increasing the application rate $(5,16)$ or by using a DMI with greater intrinsic activity. $\mathrm{EC}_{50}$ values of our mu- tants were within the range of values observed in southeastern U.S. field populations, suggesting that the underlying mechanism is likely to persist in natural populations subjected to DMI fungicide selection pressure. Thus, it is striking that, through all these years of selection pressure, no Monilinia sp., including M. fructicola, has evolved subpopulations exhibiting alterations of the DMI fungicide target site. After all, the Y136F mutation in the CYP51 gene is commonly found in other pathogens (7-9).

Mutants possessing an altered target enzyme were obtained from spores via UV irradiation in this study. None of the mutants overexpressed the CYP51 gene as established by real-time PCR (data not shown). Instead, mutants with $\mathrm{EC}_{50}$ values greater than $0.342 \mu \mathrm{g} / \mathrm{ml}$ revealed the same Y136F mutation that conferred high levels of DMI resistance in field isolates of Erysiphe graminis, Uncinula necator, Mycosphaerella graminicola, and $M$. fijiensis and laboratory mutants of Penicillium italicum (7-10,24). Also, the corresponding amino acid mutation $\mathrm{Y} 132 \mathrm{H}$ in the yeast fungus Candida albicans caused high levels of resistance to fluconazole $(3,22,23)$. In other plant pathogens, the mutation at the equivalent position provided less dramatic but still significant DMI resistance $(1,37,40)$. Based on the crystal structure of CYP51 in Mycobacterium tuberculosis, the replacement of tyrosine by phenylalanine at position 136 causes a change in the hydrophobicity of the active site belonging to substrate recognition site 1 (24). The above-mentioned associations of DMI resistance and the Y136F mutation coupled with the fact that all of our independently generated DMIresistant mutants possessed this exact mutation are very strong evidence that $\mathrm{Y} 136 \mathrm{~F}$ did confer DMI resistance in our mutants. Moreover, the resistance mechanism found in the mutants was specific to DMI fungicides, as revealed by strong cross resistance with propiconazole. We did not attempt to rescue the mutants by complementation, because such experiments have not yet been successfully conducted in Monilinia spp. Further investigations into possible mechanisms of resistance in our mutants demonstrated no point mutations in the ERG2, ERG24, and ERG27 genes encoding $\Delta 8 \rightarrow \Delta 7$ sterol isomerase, C-14 sterol reductase, and 3-keto reductase, respectively (data not shown). These genes are documented target proteins of ergosterol biosysthesis inhibitors (2).

The Y136F mutation in our mutants came with a fitness penalty, which offers an explanation for the lack of such mutations in field populations. All fitness parameters were numerically lower for the mutants as a group; however, significant differences were only found for mycelial growth rates, the ability to sporulate in vitro, and lesion diameter on detached fruit. We hypothesize that the lack of ability to produce spontaneous DMI fungicide-resistant genotypes combined with the fitness penalty (growth and sporulation) observed in Y136F mutants might contribute to the inability of the pathogen to develop stable DMI fungicide-resistant field populations based on the $\mathrm{Y} 136 \mathrm{~F}$ target site alteration.

\section{Acknowledgments}

This study was supported by the Shenyang Research Institute of Chemical Industry of China, the Program for New Century Excellent Talents in University

Table 4. Comparison of the amino acid sequence of CYP51 from SYP-Z048-resistant mutants with wild-type isolates

\begin{tabular}{|c|c|c|c|c|c|}
\hline \multirow[b]{2}{*}{ Isolate, mutant ${ }^{\mathbf{y}}$} & \multirow[b]{2}{*}{$\mathrm{EC}_{50}(\mu \mathrm{g} / \mathrm{ml})^{\mathrm{z}}$} & \multirow[b]{2}{*}{ Accession number } & \multicolumn{3}{|c|}{ Variation at amino acid position ${ }^{x}$} \\
\hline & & & 136 & 161 & 490 \\
\hline MSB11 & 0.011 & GU136400 & $\mathrm{Y}$ & $\mathrm{P}$ & $\mathrm{F}$ \\
\hline MPA18 & 0.013 & GU136401 & $\mathrm{Y}$ & $\mathrm{P}$ & $\mathrm{S}$ \\
\hline MFJ2 & 0.033 & GU136402 & $\mathrm{Y}$ & $\mathrm{P}$ & $\mathrm{F}$ \\
\hline A3081 & 0.097 & GU136403 & $\mathrm{Y}$ & $\mathrm{P}$ & $\mathrm{F}$ \\
\hline B5013 & 0.342 & GU136404 & $\mathrm{F}$ & $\mathrm{P}$ & $\mathrm{F}$ \\
\hline B6012 & 0.570 & GU136405 & $\mathrm{F}$ & $\mathrm{S}$ & $\mathrm{F}$ \\
\hline B506 & 0.820 & GU136406 & $\mathrm{F}$ & $\mathrm{P}$ & $\mathrm{F}$ \\
\hline B511 & 0.886 & GU136407 & $\mathrm{F}$ & $\mathrm{P}$ & $\mathrm{F}$ \\
\hline
\end{tabular}

${ }^{x} \mathrm{Y}=$ tyrosine, $\mathrm{F}=$ phenylalanine, $\mathrm{P}=$ proline, and $\mathrm{S}=$ serine.

${ }^{y}$ MSB11, MPA18, and MFJ2 are wild-type isolates; A3081, B5103, B6012, B506, and B511 are mutants.

${ }^{\mathrm{z}}$ Fungicide dose at which mycelium growth was inhibited by $50 \%$. 
(18011013), and the Key Projects in the National Science \& Technology Pillar Program during the Eleventh Five-Year Plan Period (2007BAD57B02).

\section{Literature Cited}

1. Albertini, C., Gredt, M., and Leroux, P. 2003. Polymorphism of $14 \alpha-$ demethylase gene (CYP51) in the cereal eyespot fungi Tapesia acuformis and Tapesia yallundae. Eur. J. Plant Pathol. 109:117-128.

2. Anonymous. FRAC. 2011. FRAC code list: fungicides sorted by mode of action. Online publication. http://www.frac.info/frac/index.htm.

3. Asai, K., Tsuchimori, N., Okonogi, K., Perfect, J. R., Gotoh, O., and Yoshida, Y. 1999. Formation of azole-resistant Candida albicans by mutation of sterol 14-demethylase P450. Antimicrob. Agents Chemother. 43:11631169.

4. Birchmore, R. J., Williams, R. J., Russell, P. E., and Lagouarde, P. 1996. A baseline for the sensitivity of Botrytis cinerea to pyrimethanil. Brighton Crop Prot. Conf. Pests Dis. 2:713-718.

5. Brannen, P. M., and Schnabel, G. 2006. Survey of Monilinia fructicola populations with reduced sensitivity to DMIs in Georgia and implications for brown rot control recommendations. (Abstr.) Phytopathology 96:S16.

6. Burnett, A., Lalancette, N., and McFarland, K. 2010. First report of the peach brown rot fungus Monilinia fructicola resistant to demethylation inhibitor fungicides in New Jersey. Plant Dis. 94:126.

7. Canas-Gutierrez, G. P., Angarita-Velasquez, M. J., Restrepo-Florez, J. M., Rodriguez, P., Moreno, C. X., and Arango, R. 2009. Analysis of the CYP51 gene and encoded protein in propiconazole-resistant isolates of Mycosphaerella fijiensis. Pest. Manage. Sci. 65:892-899.

8. Délye, C., Bousset, L., and Corio-Coste, M. F. 1998. PCR cloning and detection of point mutations in the eburicol 14 $\alpha$-demethylase (CYP51) gene from Erysiphe graminis f. sp. hordei, a 'recalcitrant' fungus. Curr. Genet. 34:399-403.

9. Délye, C., Laigret, F., and CorioCostet, M. F. 1997. A mutation in the $14 \alpha-$ demethylase gene of Uncinula necator that correlates with resistance to a sterol biosynthesis inhibitor. Appl. Environ. Microbiol. 63:2966-2970.

10. DeWaard, M. A. 1996. Molecular genetics of resistance in fungi to azole fungicides. ACS Symp. Ser. 645:62-71.

11. Fraaije, B. A., Cools, H. J., Kim, S. H., Motteram, J., Clark, W. S., and Lucas, J. A. 2007. A novel substitution I381V in the sterol $14 \alpha$-demethylase (CYP51) of Mycosphaerella graminicola is differentially selected by azole fungicides. Mol. Plant Pathol. 8:245-254.

12. Gell, I., De Cal, A., Torres, R., Usall, J., and Melgarejo, P. 2009. Conidial density of Monilinia spp. on peach fruit surfaces in relation to the incidences of latent infections and brown rot. Eur. J. Plant Pathol. 123:415-424.

13. Han, P., Liu, X .L., Liu, P. F., and Si, N. G. 2006. Effect of novel fungicide 5-(4-chloro phenyl)-2,3-dimethyl-3-(pyridine-3)-oxazoline on ergosterol biosynthesis in Botrytis cinerea by high performance liquid chromatography. Chin. J. Anal. Chem. 34:1467-1470.

14. Harada, Y., Nakao, S., Sasaki, M., Sasaki, Y., Ichihashi, Y., and Sano, T. 2004. Monilia mumeicola, a new brown rot fungus on Prunus mume in Japan. J. Gen. Plant Pathol. 70:297-307.

15. Holb, I. J., and Schnabel, G. 2006. Efficacy of an elemental sulfur/propiconazole mixture on Monilinia fructicola isolates with reduced sensitivity to DMI fungicides. (Abstr.) Phytopathology 96:S49.

16. Holb, I. J., and Schnabel, G. 2007. Differential effect of triazoles on mycelial growth and disease measurements of Monilinia fructicola isolates with reduced sensitivity to DMI fungicides. Crop Prot. 26:753-759.

17. Hong, C., Holtz, B. A., Morgan, D. P., and Michailides, T. J. 1997. Significance of thinned fruit as a source of the secondary inoculum of Monilinia fructicola in California nectarine orchards. Plant Dis. 81:519-524.

18. Ioos, R., and Frey, P. 2000. Genomic variation within Monilinia laxa, M. fructigena and M. fructicola, and application to species identification by PCR. Eur. J. Plant Pathol. 106:373-378.

19. Kalamarakis, A. E., Dewaard, M. A., Ziogas, B. N., and Georgopoulos, S. G. 1991. Resistance to fenarimol in Nectria haematococca var. cucurbitae. Pestic. Biochem. Physiol. 40:212-220.

20. Karabulut, O. A., and Baykal, N. 2003. Biological control of postharvest diseases of peaches and nectarines by yeasts. J. Phytopathol. 151:130-134.

21. Karabulut, O. A., Cohen, L., Wiess, B., Daus, A., Lurie, S., and Droby, S. 2002. Control of brown rot and blue mold of peach and nectarine by short hot water brushing and yeast antagonists. Postharvest Biol. Technol. 24:103-111.

22. Kelly, S. L., Lamb, D. C., and Kelly, D. E. 1999. Y132H substitution in Candida albicans sterol $14 \alpha$-demethylase confers fluconazole resistance by preventing binding to haem. FEMS Microbiol. Lett. 180:171-175.
23. Kudo, M., Ohi, A., Aoyama, Y., Nitahara, Y., Chung, S. K., and Yoshida, Y. 2005. Effects of Y132H and F145L substitutions on the activity, azole resistance and spectral properties of Candida albicans sterol 14-demethylase P450 (CYP51): a live example showing the selection of altered P450 through interaction with environmental compounds. J. Biochem. 137:625632.

24. Leroux, P., Albertini, C., Gautier, A., Gredt, M., and Walker, A. S. 2007. Mutations in the CYP51 gene correlated with changes in sensitivity to sterol $14 \alpha$-demethylation inhibitors in field isolates of Mycosphaerella graminicola. Pest Manage. Sci. 63:688-698.

25. Luo, C. X., Cox, K. D., Amiri, A., and Schnabel, G. 2008. Occurrence and detection of the DMI resistance-associated genetic element 'Mona' in Monilinia fructicola. Plant Dis. 92:1099-1103.

26. Luo, C. X., and Schnabel, G. 2008. The cytochrome p450 lanosterol $14 \alpha-$ demethylase gene is a demethylation inhibitor fungicide resistance determinant in Monilinia fructicola field isolates from Georgia. Appl. Environ. Microbiol. 74:359-366.

27. Luo, Y., and Michailides, T.J. 2001. Risk analysis for latent infection of prune by Monilinia fructicola in California. Phytopathology 91:1197-1208.

28. Lupetti, A., Danesi, R., Campa, M., Tacca, M. D., and Kelly, S. 2002. Molecular basis of resistance to azole antifungals. Trends Mol. Med. 8:76-81.

29. Ma, Z., Yoshimura, M. A., and Michailides, T. J. 2003. Identification and characterization of benzimidazole resistance in Monilinia fructicola from stone fruit orchards in California. Appl. Environ. Microbiol. 69:7145-7152.

30. Sanoamuang, N., and Gaunt, R. E. 1995. Persistence and fitness of carbendazim-resistant and dicarboximide-resistant isolates of Monilinia fructicola (Wint.) Honey in flowers, shoots and fruit of stone fruit. Plant Pathol. 44:448-457.

31. Sanoamuang, N., Gaunt, R. E., and Fautrier, A. G. 1995.The segregation of resistance to carbendazim in sexual progeny of Monilinia fructicola. Mycol. Res. 99:677-680.

32. Schnabel, G., Bryson, P. K., Bridges, W. C., and Brannen, P. M. 2004. Reduced sensitivity in Monilinia fructicola to propiconazole in Georgia and implications for disease management. Plant Dis. 88:1000-1004.

33. Schnabel, G., and Dai, Q. 2004. Heterologous expression of the P450 sterol $14 \alpha$-demethylase gene from Monilinia fructicola reduces sensitivity to some but not all DMI fungicides. Pestic. Biochem. Physiol. 78:31-38.

34. Si, N. G., Zhang, Z. J., Liu, J. L., Li, Z. N., Zhang, D. M., Chen, L., and Wang, L. Z. 2004. Biological activity and application of a novel fungicide: SYP-Z048(I). Chin. J. Pestic. 43:16-18.

35. Smith, D. 2010. Distribution maps of plant disease. Map50(Edition 8) Online publication. http://www.cabi.org/dmpd/default.aspx?site=165\&page $=1357 \&$ LoadModule $=$ Review\&ReviewID=134848.

36. Stammler, G., Carstensen, M., Koch, A., Semar, M., Strobel, D., and Schlehuber, S. 2008. Frequency of different CYP51-haplotypes of Mycosphaerella graminicola and their impact on epoxiconazole-sensitivity and -field efficacy. Crop Prot. 27:1448-1456.

37. Stammler, G., Cordero, J., Koch, A., Semar, M., and Schlehuber, S. 2009 Role of the Y134F mutation in CYP51 and overexpression of CYP51 in the sensitivity response of Puccinia triticina to epoxiconazole. Crop Prot. 28:891-897.

38. Vantuyl, J. M. 1977. Genetic aspects of resistance to imazalil in Aspergillus nidulans. Neth. J. Plant Pathol. 83:169-176.

39. Walter, M., McLaren, G. F., Fraser, J. A., Frampton, C. M., Boyd-Wilson, K. S. H., and Perry, J. H. 2004. Methods of screening apricot fruit for resistance to brown rot caused by Monilinia spp. Australas. Plant Pathol. 33:541547.

40. Wyand, R. A., and Brown, J. K. M. 2005. Sequence variation in the CYP51 gene of Blumeria graminis associated with resistance to sterol demethylase inhibiting fungicides. Fungal Genet. Biol. 42:726-735.

41. Yoshimura, M. A., Luo, Y., Ma, Z. H., and Michailides, T. J. 2004. Resistance of Monilinia fructicola from stone fruit to thiophanate methyl, iprodione and tebuconazole. (Abstr.) Phytopathology 94:S155.

42. Yuan, S. K., Liu, X. L., Si, N. G., Dong, J., Gu, B. G., and Jiang, H. 2006. Sensitivity of Phytophthora infestans to flumorph: in vitro determination of baseline sensitivity and the risk of resistance. Plant Pathol. 55:258-263.

43. Zehr, E. I., Luszcz, L. A., Olien, W. C., Newall, W. C., and Toler, J. E. 1999. Reduced sensitivity in Monilinia fructicola to propiconazole following prolonged exposure in peach orchards. Plant Dis. 83:913-916.

44. Zwiers, L. H., Stergiopoulos, L., Van Nistelrooy, J. G. M., and De Waard, M. A. 2002. ABC transporters and azole susceptibility in laboratory strains of the wheat pathogen Mycosphaerella graminicola. Antimicrob. Agents Chemother. 46:3900-3906. 